(11) Nordic Council of Ministers
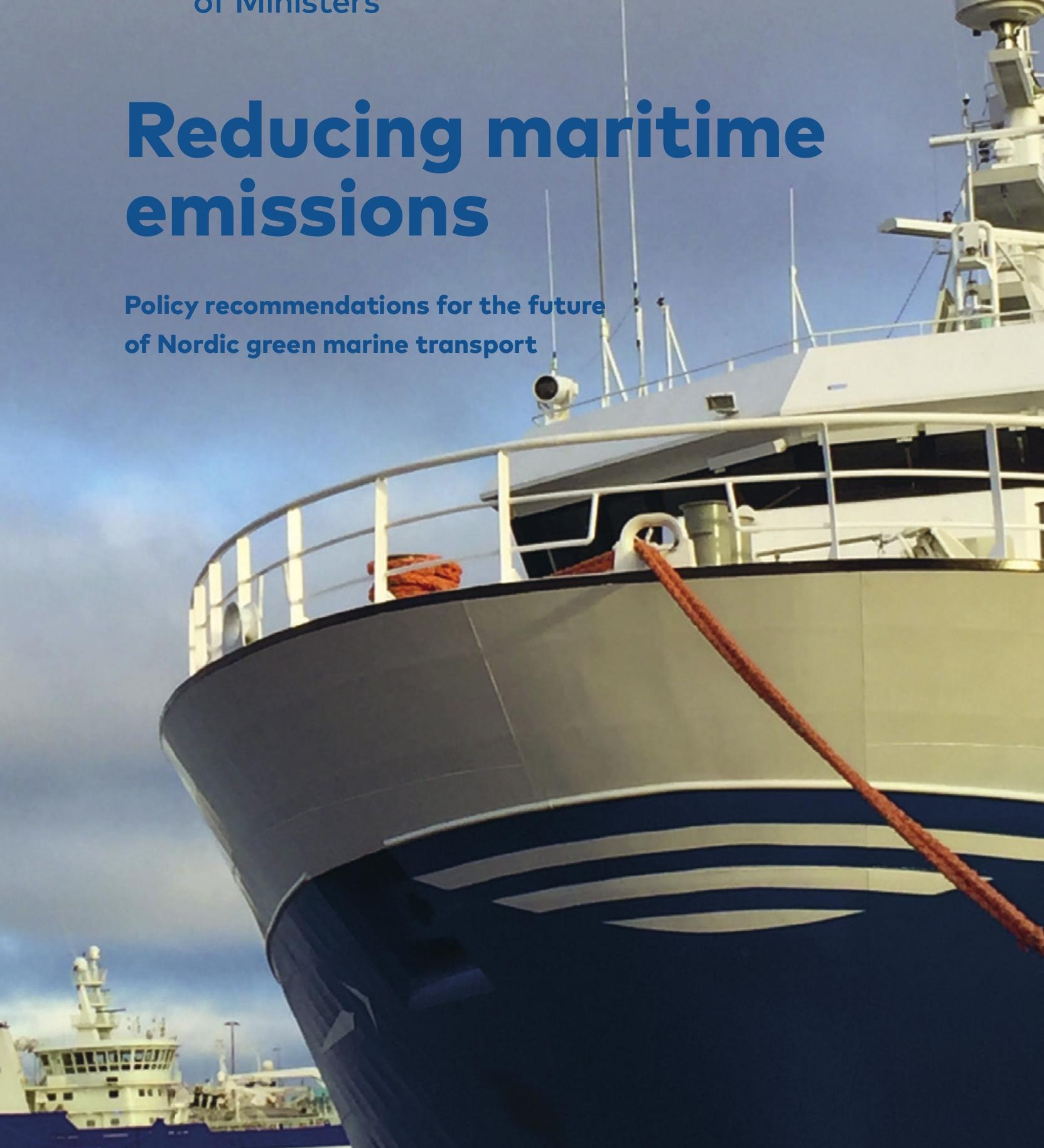



\title{
Reducing maritime emissions
}

\author{
Nordic Marina
}

TemaNord 2017:511 


\section{Reducing maritime emissions}

\section{Nordic Marina}

ISBN 978-92-893-4896-6 (PRINT)

ISBN 978-92-893-4897-3 (PDF)

ISBN 978-92-893-4898-o (EPUB)

http://dx.doi.org/10.6027/TN2017-511

TemaNord 2017:511

ISSN 0908-6692

Standard: PDF/UA-1

ISO 14289-1

(C) Nordic Council of Ministers 2017

Layout: NMR

Cover photo: Sigríður Ragna Sverrisdóttir

Print: Rosendahls

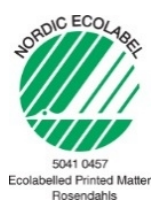

Although the Nordic Council of Ministers funded this publication, the contents do not necessarily reflect its views, policies or recommendations.

\section{Nordic co-operation}

Nordic co-operation is one of the world's most extensive forms of regional collaboration, involving Denmark, Finland, Iceland, Norway, Sweden, the Faroe Islands, Greenland, and Åland.

Nordic co-operation has firm traditions in politics, the economy, and culture. It plays an important role in European and international collaboration, and aims at creating a strong Nordic community in a strong Europe.

Nordic co-operation seeks to safeguard Nordic and regional interests and principles in the global community. Shared Nordic values help the region solidify its position as one of the world's most innovative and competitive. 


\section{Contents}

Executive summary

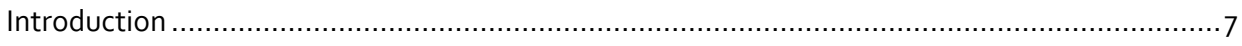

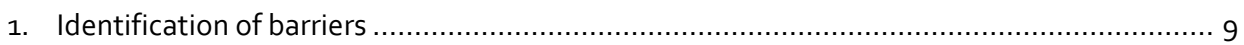

1.1 Government initiative and contribution ...................................................... 9

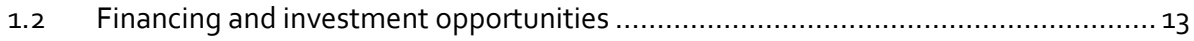

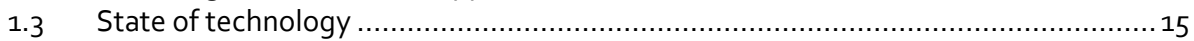

1.4 Research and development, education, reporting ………..................................... 17

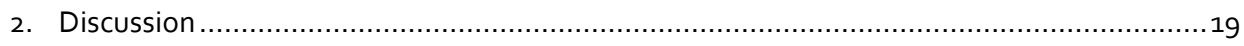

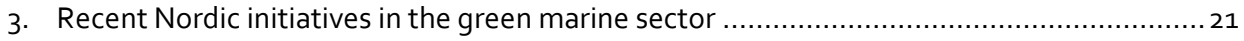

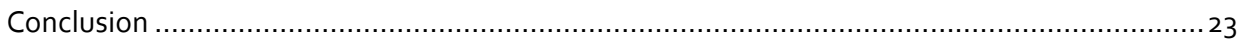

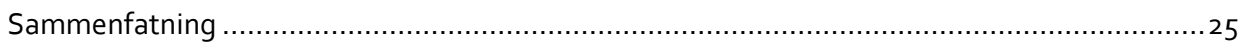





\section{Executive summary}

As Nordic Marina's work under the umbrella project of NordBio comes to a close, it is important to share the findings and information gathered during the course of the project's lifetime. This paper discusses and provides an analysis of feedback from participants in Nordic Marina meetings, workshops, seminars and conferences and stakeholders in various marine- and maritime-related Nordic industries.

An overarching conclusion reveals that the global, and indeed the Nordic shipping and maritime industries, are already boldly moving ahead with regard to emissions reduction, boasting numerous innovative and successful projects contributing toward this goal. However, in order to take major steps forward, involvement from the government side is needed and currently lacking. There are barriers that industry and government must work on collectively, potentially via joint public-private partnerships. Commitment for the long term, irrespective of political terms is essential, in addition to the demand for strengthening infrastructure and a reliable supply chain to support new fuels. Furthermore, the socio-economic benefits of emissions reduction and the applications of alternative fuels appear to be obscure. Incorporating social and environmental savings in private sustainability endeavours and public tenders, for example, can reveal indirect income and benefits for corporations and certainly for society as a whole. The introduction of tax incentives for early adopters of alternative fuels and emissions reduction technologies and application of other policy instruments are likely to accelerate progress toward sustainability goals, as has been clear in the case of land transport. 
Interestingly, as Nordic Marina's formal project period comes to a close, the global community also stands at a crossroads. As of December 2016, 120 of 197 parties to the UNFCCC Convention have ratified the Paris Agreement. That is, a majority of parties have agreed to adhere to the long-term goal of maintaining the global average temperature increase to within $2^{\circ} \mathrm{C}$. Without question, shipping can contribute to this goal. The focus need not solely be on alternative fuels, rather a host of other commercial solutions to increase efficiency and performance provide important support while the fuels of the future are being developed. The bottom line is this: the time for action is now, for all of us. 


\section{Introduction}

Since its creation, the goal of Nordic Marina has been to evaluate potential in the Nordic countries to reduce $\mathrm{CO}_{2}$ emissions from the marine industry. For this purpose, stakeholders were brought together to reflect on the status of projects and activities and discuss possible pathways for next steps. This paper discusses key issues raised by stakeholders and reflects on possible policy actions to encourage the adoption and further development of alternative fuels and technology, bringing the Nordic region to the forefront in sustainable, green marine solutions. Ultimately, different stakeholders all have common goals: maintaining clean oceans, supporting healthy port communities and contributing to achieving global, regional and national climate goals while providing sustainable supply chains for goods and services to the marine sector. 



\section{Identification of barriers}

Participants in Nordic Marina workshops were asked to identify existing barriers to the further development and adoption of alternative fuels in the maritime sector and the reduction of related emissions. For the sake of clarity, barriers have been arranged into several groups according to theme:

- Government initiative and contribution.

- Financing and investment opportunities.

- State of technology:

- Infrastructure.

- $R D \& D$, reporting and information.

Each of these categories will be discussed individually and in depth.

\subsection{Government initiative and contribution}

Marine sector stakeholders have expressed concern about the lack of both government initiative and interest in promoting alternative fuels and related projects for marine applications. This pertains to economic policy instruments, such as taxes, spending and incentives and regulations, voluntary and legal. An overwhelming number of participants in Nordic Marina workshops declared the need for clear policy and the introduction of simple yet effective incentives. This would communicate the clear message to the industry, the public and other policymakers that the government is not only interested in but also prepared to actively support the issue and its stakeholders. Commitment for not only the short term, which coincides with political terms, but also concrete, long-term engagement is what industry players are clamoring for. The timeframe for incentives is therefore of high importance and must realistically be taken into account. 
Developers of new transport technologies and environmentally sound fuels also reported during Nordic Marina workshops that any contingencies or uncertainties regarding the time at which rules and standards come into force make the environment for green fuels risky to investors. Without clear government communication on energy and environmental policy for the long term, creating investment opportunities for green fuels in maritime applications is quite challenging.

Stakeholders are reluctant to adopt technology that does not have readily available infrastructure and a reliable supply chain. This pertains to what is called the "chicken or the egg problem", in which the dilemma is which should come first, infrastructure or users. Governments and investors are equally cautious investing in infrastructure for new technology until they are satisfied that there is an existing market of users. The mindset in making procurement decisions based almost solely on payback time could benefit from taking into account a broader set of factors, such as total lifetime cost, reduction of greenhouse gas emissions, local air quality improvement and other innovative procurement practices. This is a more complex issue compared to providing infrastructure for land-based use, as the lifetime of vessels is at least three times longer than for vehicles.

Norway and Iceland's success in electrifying its fleet of passenger vehicles has been evident. This has been made possible, for the most part, due to extensive government incentives such as exemption from vehicle fees and VAT on purchases, making the total cost of operation (TCO) of electric vehicles competitive with that of conventional internal combustion engine vehicles.

Figure 1: With realistic policy setting, incentives and investment in infrastructure, a major accomplishment has been achieved in Norway and Iceland introducing BEVs

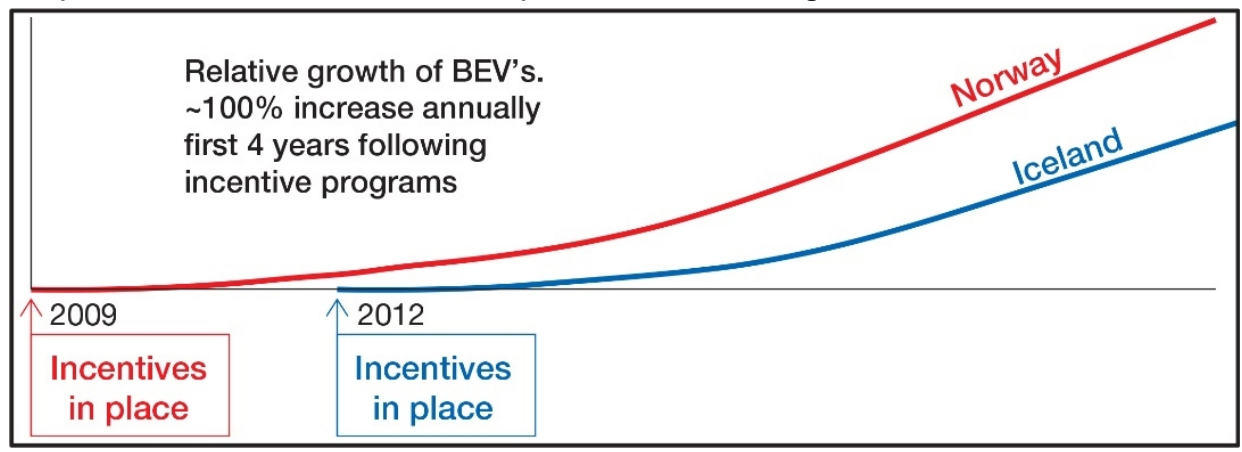


Figure 1 demonstrates that major impacts can be accomplished with strong government policy and a joint public-private partnership for introducing a new technology to a very mature market. Governments can make use of public-private stakeholder groups when formulating policy, which, at the same time, should have synergies between marine and land transport. The Nordic countries are located around the fragile Arctic, and some countries have taken a lead in policy steps toward land transport; this should also be the case for marine applications.

Governments should also take the lead while new technology goes through its infancy by, for example, utilising new solutions and eco-friendly fuels in state-owned vessels.

Government support for small businesses, new and established enterprises, working on innovative solutions is vital for new technology to develop further outside of the laboratory. Transforming a good idea into a viable business offering a product that improves not only the local environment, but the global community as well, requires first and foremost access to financial resources and support. This is not a one-way action. The industry is ready and willing to participate. A joint public-private partnership to formulate a long-term policy and action plan could be a beneficial practice for all parties.

Figure 2: Grams $\mathrm{CO}_{2}$ emitted transporting one tonne one kilometer, for different transport modes ${ }^{1}$

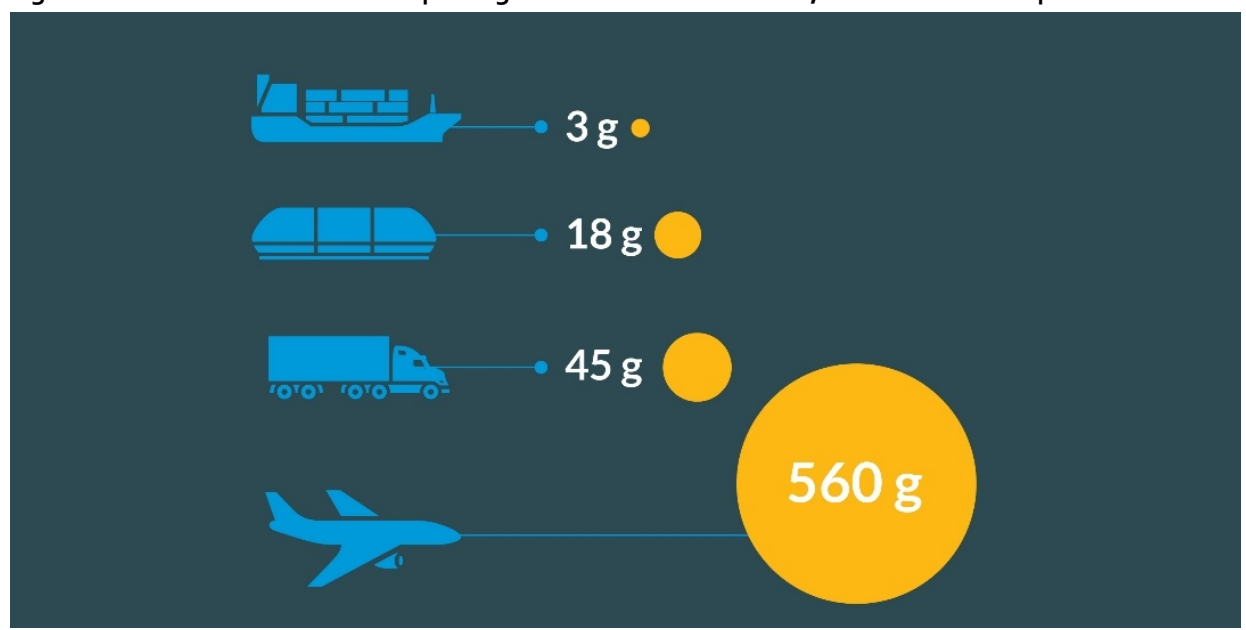

${ }^{1}$ The Maersk Group. (n.d.). Environment. Retrieved on 4 September 2016 from http://www.maersk.com/en/hardware/triplee/environment 
There are drastic socio-economic benefits to be achieved. Already, sea transport is the most eco-friendly way of transporting goods, as is demonstrated in Figure 2. There are direct social and economic benefits of increasing the use of marine transport, and the benefits can be greatly increased with the use of eco-friendly fuels in ships. As an example in the ZERO.8 JUP ZVT initiative, ${ }^{2}$ which analyzed the socio-economic benefits of reducing emissions from shipping for various projects, it was identified that the pilot project Stena Germanica monitized annual benefits to the society equal to 563 KEUR, despite not considering the effect of reduced NOx emissions. Other pilot projects ${ }^{2}$ such as $L N G_{4}$ Solution and $L N G$ CONV bring socio-economic benefits of 765 KEUR and 862 KEUR respectively on an annual basis. These benefits are brought by $\mathrm{SO}_{x}$ and PPM emissions reduction and their effect on life quality, health care cost reduction and crop growth benefit. Pure electric propulsion using renewable energy and batteries, or hydrogen and fuel cells, can even provide larger benefits. Based on the benefits accounting for the natural and social capital, more conversion projects with methanol and other alternative fuels can also expect funding and subsidies from governments and other bodies, making the business case more economically feasible and sustainable. If strong regulations on carbon dioxide emissions are implemented, alternative fuels can be competitively used with a $\mathrm{CO}_{2}$-neutral impact. In this context, though, it is important that any actions do not push goods from ships to land transport. Potentially, further research is needed for this topic both regarding socio-economic studies and to avoid any policy actions that might shift the transport of goods from sea to land. This includes studies such as LCAs for vessels compared to land transport, etc.

This brings us to the next significant hurdle that most stakeholders report must be overcome for the advance of green fuels: money.

2 Stefan Åström. (2015). Estimating the socio-economic benefits of reducing emissions from shipping - ZVT case studies. Retrieved on February 92017 from http://www.zerovisiontool.com/sites/www.zerovisiontool.com/files/attachments/zvt_day_150921_jupo8_air_results_ivl_webb.pdf 


\section{Key findings on government contribution:}

- Key message: Commitment and concrete, long-term engagement of government is required.

- Key message: Innovative procurement takes into account a broader set of factors than current conventional monetary value-focused procurement practices.

- Key message: A phase out of fossil fuel subsidies would create a more equal playing field for alternative fuels and encourage their adoption.

- Possible policy action: Long-term policy must create an enabling environment for the transition from fossil-based fuels.

- Possible policy action: Direct involvement in supporting infrastructure build-up to help solve the "chicken and egg" dilemma.

- Possible policy action: Implement green public procurement practices.

- Possible policy action: Design and utilise policy instruments that promote innovation and competitiveness of green fuels.

- Possible policy action: Regulating harbour emissions promotes healthy port communities and provides motivation for examining alternative fuels and green technologies. Example: offer lowemissions vessels discounted harbour fees (Port of Amsterdam).

\subsection{Financing and investment opportunities}

Novel technologies generally carry high capital expenditure, and this is a concern for the maritime industry. Some of the solutions ready for adoption are not cost effective, and for many companies, this is reason enough to postpone the shift away from fossil fuels for another few years or decades. For the fuel-saving technologies that are on the cusp of commercial viability, providing guaranteed results and value to potential investors and clients is important for commercial credibility and market presence. Pilot projects that demonstrate new technology and also establish the real possibility of reduction in fuel costs will break ground for new technologies. A good example is the batterypowered car ferry operating in Sognefjord in Norway, which has shown that fuel costs can be reduced by more than 60 percent.

However, viewing technologies as services upon investment rather than focusing on instant payback may prove helpful to early adopters. Incorporating social and environmental cost savings in sustainability reports can reveal indirect income and benefits for society. 
Although funding opportunities exist, nationally, across the Nordic countries and the EU, many stakeholders feel funds are geared toward supporting innovation almost exclusively. It is equally important to finance projects that have completed feasibility studies and require a boost in order to reach market. Finally, uncertainties regarding the timeframes for economic incentives, such as tax expentitures to encourage certain behaviour and subsidies to encourage production, have resulted in delayed investment processes according to stakeholders. This relates to the discussion in the previous section on government initiative and contribution.

Norway has already taken some actions by setting up its NOx fund, through which companies contribute a participant fee in lieu of a NOx tax. The funds are in turn used for cleaning the industry. This is a prime example of a policy tool that could be established to accelerate emissions reduction. In addition, the Norwegian government funding instrument, ENOVA, now supports infrastructure for electrical vessels and energysaving technologies installed in vessels.

The current competitive environment is fairly difficult for green fuels; there is a definite need to create an equal playing field for alternative and conventional fuels.

\section{Key findings on financing and investment:}

- Key message: There is a need for increased funding opportunities and economic in-centives to tackle high capital expenditure.

- Key message: Market take-up requires policy action.

- Possible policy action: The introduction of tax incentives for early adopters of alternative fuels and emissions-reduction technologies. Example: incorporating social and environmental cost savings into fuel price.

- Possible policy action: Increase funding to commercialise research.

- Possible policy action: Promote green investment.

- Possible policy action: Develop a policy framework for market development of alternative fuels and infrastructure. 


\subsection{State of technology}

Although the switch to alternative fuels is essential to breaking the dependence upon fossil fuels, the process is a complex one and will take decades to implement fully. This has been made clear by shipowners, cargo owners and other industry players. Existing infrastructure, which is for liquid and gaseous fossil fuels, does not support all new fuels and energy carriers. As demand for electricity increases in harbours, major investments will be required to strengthen the grid. Moreover, due to the varying physical and chemical properties of the fuels, storage solutions differ, as do handling requirements. For example, energy densities vary enormously in commonly used energy storage materials, ranging from $1 \mathrm{MJ} / \mathrm{L}$ for a lithium ion battery to forty times that for fossil fuels. In other words, fossil fuels require forty times less space (volume) than an energy-equivalent battery, but at the same time, an electrical motor is much more energy efficient than a combustion motor ( 90 versus 30 in energy efficiency). Differing properties and consumption processes also result in a host of waste products and emissions to air, water and sometimes to soil, requiring varying degrees of aftertreatment and recycling of components and waste.

Most existing marine vessels are built to burn fossil fuels such as marine gasoil and marine diesel and therefore are not fit to switch to just any alternative fuel. Therefore, ships either may be retrofitted to run on a different energy carrier, with great expense, or may be retrofitted with auxiliary energy-saving technologies. The average lifetime of a cargo vessel is at least 30 years, thus requiring shipowners to plan decades ahead for vessel investment and renewal. Furthermore, the availability and price of different fuels must also be taken into account, not to mention the accessibility of infrastructure and relevant service in destination ports around the world.

Maritime connectivity has been on the rise and will continue to advance in the coming years. Digitalisation in shipping has great potential to improve efficiency and thus reduce emissions. In fact, some estimations predict digitalisation has the emissions-reduction potential of up to and even greater than $20 \%$. Stakeholders have spotlighted the importance of appreciating the value of this emissions reduction, despite it not being by virtue of the implementation of a non-fossil fuel.

While securing funding for basic research has usually been the role of government and the private sector has supported commercial products and technology, both have been reluctant to finance infrastructure for alternative fuels. Some await a clear winner 
in replacing fossil fuels, while other stakeholders face the chicken versus the egg dilemma mentioned earlier: waiting for a sizable market of users for which to invest in infrastructure, resulting in little or no progress.

Finally, stakeholders have also expressed an urgent need for standardisation of alternative fuels and technologies. This is a necessary condition for increased promotion and adoption of alternative fuels, and no less importantly, the general acceptance of engine and vehicle manufacturers, in addition to fuel distributors.

Going from fossil-based fuels to alternatives is not the only pathway to reduce $\mathrm{CO}_{2}$ and other emissions. Various actions can and have been implemented. These can include:

- Improved ship design.

- Coatings for resistance reduction.

- Lightweight materials.

- Sophisticated energy management and control systems.

- Energy-saving electric utilities and batteries.

- Supplementary power-generation technologies, such as wind and solar.

- Waste management.

- Engine efficiency.

These are mere examples; when all of these are brought together, a new vessel, even one running on fossil fuel, could save up to $50 \%$ of what a 30 -year-old, comparably functioning ship is using. This is a development similar to that within the car industry in the last decade. Stimulating the uptake of cutting-edge technology is therefore also a very important task in adressing $\mathrm{CO}_{2}$ emissions.

\section{Key findings for the state of technology:}

- Key message: There is a clear need for infrastructure to support different fuels in harbours and existing vessels in order to promote the availability of alternative fuels.

- Key message: Different energy carriers call for the availability of different storage and treatment solutions.

- Key message: Encouragement to adopt new technology for current ship fleet.

- Possible policy action: Develop sound business cases for the investment in infra-structure.

- Possible policy action: Support the accelerated standardisation of alternative fuels and technologies. 


\subsection{Research and development, education, reporting}

The further development of new and existing alternative marine fuels and technologies is a principal factor in meeting reduction targets and climate goals, be they national, regional or global. Though the Nordic countries have created numerous successful and innovative marine projects (see example project list at http://nordicmarina.com/) that have received grants from national, Nordic and EU funds, key marine stakeholders report the need for investment grants that are not limited to innovation. The deployment of technology must be accelerated.

As has previously been covered, the availability of infrastructure and fuels require further study. Because different solutions are being tested and since it is unlikely that there will be a clear winner in the near future, it is also necessary to study the availability of future fuels as well as conduct LCA studies for different fuel pathways.

Equally important is the reporting of advances made with RD\&D projects and promoting the advantages of adopting green fuels. The immense opportunities in new and existing green technology must be publicised on a greater scale in order to better reach and inform the public, influencers, decision makers and potential buyers.

On a smaller, local scale, education and information sharing is just as important. Often, small groups of researchers are working on similar projects but do not have a platform for information exchange, resulting in a degree of unnecessary fragmentation. At times, this is also the case with projects in the Nordic countries, though Nordic co-operation has generally been a prosperous one. Nordic projects are easier to manage than larger, EU-scale endeavours and allow for important collaboration resulting in Nordic regional benefits. In this regard, Nordic Marina and its many local counterparts can play a valuable role in stimulating interaction between Nordic stakeholders and promote the function of networking.

Stakeholders at Nordic Marina workshops have indicated that training of harbour staff with regards to different fuels is lacking. Currently, harbour personnel are versed only in the handling of fossil fuels and related infrastructure. Managers are charged with making their companies or institutions the greatest profit, using the least amount of materials and resources while, at the very least, appearing environmentally conscious and addressing issues of sustainability. The green bottom line is not appreciated to the same extent. 


\section{Key findings in research and development:}

- Key message: Improve information flow on low- and zero-emissions projects to the public, influencers, decision makers and potential investors.

- Key message: Further stimulate networks and information exchange on a smaller, local scale to reduce fragmentation.

- Key message: Make access to information on current and new technology easier for crews: online courses, flexible e-learning.

- Possible policy action: Promote existing or establish local, national and regional platforms for stakeholders.

- Possible policy action: Fund academic networks to strengthen collaboration and information sharing. 


\section{Discussion}

Having gathered valuable information and feedback from key marine industry players in the Scandinavian countries, a theme has clearly presented itself. At the end of the day, the key message is this: the industry is not only interested, but also very willing to commence the inevitable shift away from fossil fuels and to contribute to the reduction of global greenhouse gas emissions and local pollution. When ranking the different barriers according to importance to overcome, the voices of industry stakeholders are unanimous. Leadership and initiative from the government is called for. Subsidies or other concessions are needed in order to make new technologies closer to being competitive with established, conventional fuels and technology. Further research, development, demonstration and funding thereof is essential to the advance of novel green technologies.

As has been made relevant to this discussion, Norway has had tremendous success in increasing the share of zero-emissions vehicles to land transport since implementing extensive incentives and tax concessions. This is evident when summarising the advances made in each of the five Nordic countries with regard to greening land transport and marine transport respectively, as shown in Table 1. Government policy and actions in favour of low- and zero-emissions technology in Norway and Iceland and, to a lesser extent, in Denmark, have clearly established a presence of alternative fuel vehicles. However, actions and targets for marine transport are indeed lagging, with corresponding mediocre results in all five countries, with Norway again being the exception. In fact, a recent Nordic Marina workshop in Bergen revealed that only Norway boasts a clear policy when it comes to definitive targets for change within the marine sector. This is further reflected in the number of projects and activities taking place in the Nordic countries, where Norwegian initiatives are leading other countries. Nonetheless, each nation has made notable efforts in that direction by, for example, supporting specific projects and providing some infrastructure. Certainly, this is an issue for decision makers to address and take into account, given the ambitious climate goals set for 2020, 2025 and 2030. 
Table 1: Overview of Nordic government policy and actions for the promotion of alternative fuels in land and marine transport

\begin{tabular}{|c|c|c|c|c|c|c|c|c|c|}
\hline Country & Transport & $\begin{array}{c}\mathrm{CO}_{2} \text { tax } \\
\text { incentive }\end{array}$ & $\begin{array}{c}\text { Vat } \\
\text { incentive }\end{array}$ & $\begin{array}{l}\text { Provision } \\
\text { of infra- } \\
\text { structure }\end{array}$ & $\begin{array}{c}\text { Procure- } \\
\text { ment }\end{array}$ & $\begin{array}{l}\text { Govern- } \\
\text { ment } \\
\text { policy }\end{array}$ & $\begin{array}{l}\text { RD/D } \\
\text { funding }\end{array}$ & $\begin{array}{l}\text { Adoption in- } \\
\text { ternational } \\
\text { standards }\end{array}$ & $\begin{array}{c}\mathrm{CO}_{2} \\
\text { specific } \\
\text { targets }\end{array}$ \\
\hline DK & Marine & -- & -- & -- & -- & -- & $+/-$ & ++ & -- \\
\hline & Land & + & -- & + & + & ++ & + & ++ & ++ \\
\hline $\mathrm{Fl}$ & Marine & -- & -- & -- & -- & -- & + & ++ & $+1-$ \\
\hline & Land & -- & -- & $+/-$ & -- & $+1-$ & + & ++ & ++ \\
\hline NO & Marine & -- & -- & -- & -- & -- & -- & -- & -- \\
\hline & Land & ++ & ++ & $+/-$ & -- & ++ & - & ++ & + \\
\hline IS & Marine & -- & -- & $+/-$ & + & + & ++ & ++ & + \\
\hline & Land & ++ & ++ & ++ & + & ++ & ++ & ++ & ++ \\
\hline SE & Marine & -- & -- & -- & -- & -- & + & ++ & $+/-$ \\
\hline & Land & -- & -- & $+/-$ & $+/-$ & + & + & ++ & ++ \\
\hline
\end{tabular}




\section{Recent Nordic initiatives in the green marine sector}

Table 2: Examples of recent Nordic green marine initiatives

\begin{tabular}{|c|c|c|}
\hline Project name & Goal/Scope & Keywords \\
\hline EffShip & $\begin{array}{l}\text { Improving the efficiency of the ship machinery, introducing alter- } \\
\text { native marine fuels, using wind energy as a complementary pro- } \\
\text { pulsion force and developing applicable technology for reducing } \\
\text { the emissions of } \mathrm{CO}_{2} \text {, NOx, SOx and PM. }\end{array}$ & $\begin{array}{l}\text { Efficiency, wind pro- } \\
\text { pulsion, emissions re- } \\
\text { duction }\end{array}$ \\
\hline Folgefonn project & $\begin{array}{l}\text { Demonstration of plug-in and hybrid solutions for low emission } \\
\text { technologies for short sea shipping. }\end{array}$ & $\begin{array}{l}\text { Plug-in solution, hy- } \\
\text { brid solution, short } \\
\text { sea shipping }\end{array}$ \\
\hline E-ferry project & $\begin{array}{l}\text { Demonstration project for the design and building of a prototype } \\
\text { electric ferry. }\end{array}$ & $\begin{array}{l}\text { Electric ferry, } \\
\text { emissions reduction }\end{array}$ \\
\hline Hydrogen Luxury yatcht & $2 \mathrm{MW}$ fuel cell system for a $95 \mathrm{ft}$. luxury yacht. & Fuel cell, yacht \\
\hline GreenPilot & $\begin{array}{l}\text { Pilot boat powered by methanol, conversion of diesel to metha- } \\
\text { nol. }\end{array}$ & Methanol, pilot boat \\
\hline Joules & $\begin{array}{l}\text { The JOULES proposal aims to significantly reduce the gas emis- } \\
\text { sions of European built ships, including } \mathrm{CO}_{2}, \mathrm{SO} \text {, NOx and partic- } \\
\text { ulate matters. }\end{array}$ & $\begin{array}{l}\text { Emissions reduction, } \\
\text { particulate matter }\end{array}$ \\
\hline Maritime SHIFT - SFI & $\begin{array}{l}\text { Development of intergrated, highly efficient and environmentally } \\
\text { friendly energy systems and ship operations for the maritime in- } \\
\text { dustry. }\end{array}$ & $\begin{array}{l}\text { Efficiency, } \\
\text { environmentally } \\
\text { friendly energy }\end{array}$ \\
\hline NORLED & $\begin{array}{l}\text { Batteries added to a full scale diesel electric ferry, only powered } \\
\text { by electricity. }\end{array}$ & Electric ferry \\
\hline Norsepower & Auxiliary Wind Propulsion Solution for large vessels. & Wind propulsion \\
\hline RENSEA II & $\begin{array}{l}\text { Test hybrid - batteries and diesel electric systems in combination } \\
\text { with sails. Unique regeneration system to be developed in con- } \\
\text { junction with the hybrid system. }\end{array}$ & $\begin{array}{l}\text { Battery electric, sail- } \\
\text { boat, regenerative } \\
\text { system }\end{array}$ \\
\hline
\end{tabular}


Shipping Emissions in the Arctic-Effective Control Strategies for Black Carbon, SEA-EFFECTS BC

SELFA

Ship Energy Efficiency Technologies - SET

SPIRETH

$\mathrm{MefCO} 2$

Urban Water Shuttle

Zero vision tool - Pilot Methanol

VG Ecocoaster

The ReVolt

ReCharge
The project aims at more reliable and unequivocal basis of black carbon (BC) emission evaluation to shipping environment, and towards new options for on-line monitoring techniques.

Battery hybrid fishing vessel. $70 \%$ of the energy utilised for a 10 hour fishing trip to come from the batteries $-30 \%$ from the diesel genset -240 trips per year.

Employing the simulation platform to utilize new energy-saving technologies and to seek new innovative ways to improve ship overall energy efficiency.

Methanol as a clean, low-emission alternative ship fuel (FP7).

Synthesis of methanol from captured carbon dioxide and surplus electricity.

Concept development, market analysis, pre-demonstration.

Demonstration of cost effective, clean and easy-to-handle fuel alternative with an easy infrastructure implementation. The diesel engine vessel Stena Germanica will be converted to run on methanol. Local infrastructure will be adapted to handle methanol as a marine fuel.

2 Ecocoaster cargo ships from Royal Bodewes operating on biofuel and MGO. Aim is to halve fuel consumption compared to conventional cargo vessels.

Development of a revolutionary concept for an unmanned, zeroemission, shortsea vessel.

ReCharge will review the practicalities of expanding the availability of shore power at Norway's ports, and research different power systems, such as battery-powered vessels and hybrids.
Emissions control black carbon

Battery, hybrid, fishing vessel

Efficiency, energy saving technology

Methanol, low emission fuel

$\mathrm{CO}_{2}$ capture methanol synthesis

Concept development

Stena Germanica, methanol

Biofuel, MGO, reduced fuel consumption

Unmanned vehicle, zero emission, short sea shipping

Shore power, power systems, battery power, hybrid 


\section{Conclusion}

In looking to the future, it is likely the Nordic maritime industry, and indeed the global industry, will see a combination of fuel types emerge in conjunction with novel propulsion technologies and emissions-reduction systems. The significant challenges faced in the coming years will be met on a local, regional and global scale, but it remains difficult to single out a solution that meets all requirements in addition to cost and payback requirements. Marine transport fuels and technologies are not solely procured by the vessel owner, as is the case for land transport. However, it is clear that the future lies in greening the industry: efficient marine vessels causing minimal health and ecological damage. Achieving this goal will require colossal efforts via collaboration between the industry, regulators, port authorities and communities around the world. This, our common goal is nevertheless one that is attainable, relevant and worthwhile for all.

\section{Nordic Marina background}

The overall goal of the Nordic Marina project is to reduce the $\mathrm{CO}_{2}$ footprint of marine applications. Nordic Marina set out to achieve this through connecting relevant stakeholders and policy makers to help ensure the efficient use of resources and the reduction of GHG emissions related to marine applications.

Over the course of 2015 and 2016, Nordic Marina held seven workshops, two of which were specifically aimed at bringing together public and private stakeholders/actors/players and gathering information on opportunities in the green marine fuel sector. Topics for discussion were decided upon beforehand, and participants were divided into groups, each addressing one topic with the guidance of a facilitator, who also was responsible for minutes from the group's deliberation. The outcome of each workshop was an overview of barriers to new technology adoption, opportunities in marine industries and distinct means by which the barriers may be overcome.

The partners involved in the organisation of Nordic Marina workshops and think tanks include but are not limited to: NCE Maritime CleanTech (NO), Tekes (FI), Dan-ish Maritime (DK), Swedish Maritime Administration (SE), Icelandic Transport Au-thority (IS), Wärtsilä (SE), National Energy Authority (IS) and, acting as Nordic Marina's Secretariat, Icelandic New Energy (IS).

Marking the conclusion of its formal working period, Nordic Marina set out to com-pile the knowledge and feedback obtained at its workshops to produce a Nordic Roadmap for technological development and further movement toward greening the Nordic maritime sector. This white paper is the 
product of Nordic Marina's networking efforts and information gathering among Nordic stakeholders. It deals not only with the barriers to a greener marine industry, but also, and more importantly, with the great opportunities that emerge with the adoption and promotion of alternative fuels. 


\section{Sammenfatning}

Da Nordic Marina's arbejde under paraplyprojektet NordBio nærmer sig sin afslutning, er det vigtigt at dele de resultater og oplysninger, der er blevet indsamlet i løbet af projektets levetid. Dette dokument behandler og analyserer tilbagemeldinger fra deltagere i Nordic Marina møder, workshops, seminarer og konferencer, samt fra interessenter indenfor forskellige marine- og maritimrelaterede nordiske industrier.

Den overordnede konklusion afslører, at de globale, og i særdeleshed de nordiske, shipping- og maritime industrier, allerede beslutsomt fortsætter med reduktion af udledning, med adskillige nyskabende og vellykkede projekter, der medvirker til at nå dette mål. Det er dog nødvendigt med regeringsmæssig involvering for at være i stand til at gøre væsentlige fremskridt, hvilket mangler i øjeblikket. Der findes forhindringer, som industri og regering skal samarbejde omkring, muligvis gennem offentligt-private partnerskaber. Det er afgørende at forpligte sig på lang sigt, uden hensyntagen til politiske valgperioder, udover nødvendigheden af at styrke infrastruktur og en pålidelig forsyningskæde til at understøtte nye brændstoffer. Derudover er de socioøkonomiske fordele ved reduktion af udledning og indsættelsen af alternative brændstoffer stadig uklare. Indarbejdelse af sociale og miljømæssige besparelser i private bæredygtighedsinitiativer og offentlige udbud, for eksempel, kan afsløre indirekte indtægter og fordele for selskaber og helt sikkert for samfundet som helhed. Indførelsen af skattefordele for pionerer indenfor alternative brændstoffer og teknologier til reduktion af udledning, samt anvendelse af andre politiske instrumenter, vil formentlig fremme udviklingen henimod bæredygtige mål, hvilket har vist sig at være tilfældet indenfor landtransport. 
Det er interessant, at verdenssamfundet står ved en skillevej, her hvor Nordic Marina's formelle projektperiode nærmer sig sin afslutning. Fra og med december 2016 har 120 ud af 197 parter i UNFCCC-konventionen ratificeret Paris-aftalen. Det vil sige, at flertallet af parter har accepteret at overholde det langsigtede mål med hensyn til at holde den globale temperaturforhøjelse indenfor $2{ }^{\circ} \mathrm{C}$. Shipping kan uden tvivl bidrage til dette mål. Der bør ikke udelukkende være fokus på alternative brændstoffer, men snarere et væld af kommercielle løsninger til at øge effektiviteten og ydelsen og yde vigtig støtte mens fremtidens brændstoffer bliver udviklet. I sidste ende er det tid at gøre noget, og det gælder os alle. 
Nordic Council of Ministers

Ved Stranden 18

DK-1061 Copenhagen K

www.norden.org

\section{Reducing maritime emissions}

An overarching conclusion of Nordic Marina's work in the past three years reveals that the global, and indeed the Nordic shipping and maritime industries, are already boldly moving ahead with regard to emissions reduction, boasting numerous innovative and successful projects contributing toward this goal. In order to take major steps forward, involvement from the government side is needed and currently lacking. There are barriers that industry and government must work on collectively, potentially via joint public-private partnerships. Commitment for the long term is essential, in addition to the demand for strengthening infrastructure and a reliable supply chain to support new fuels. Furthermore, the socio-economic benefits of emissions reduction and the applications of alternative fuels appear to be obscure. The bottom line is this: the time for action is now, for all of us. 